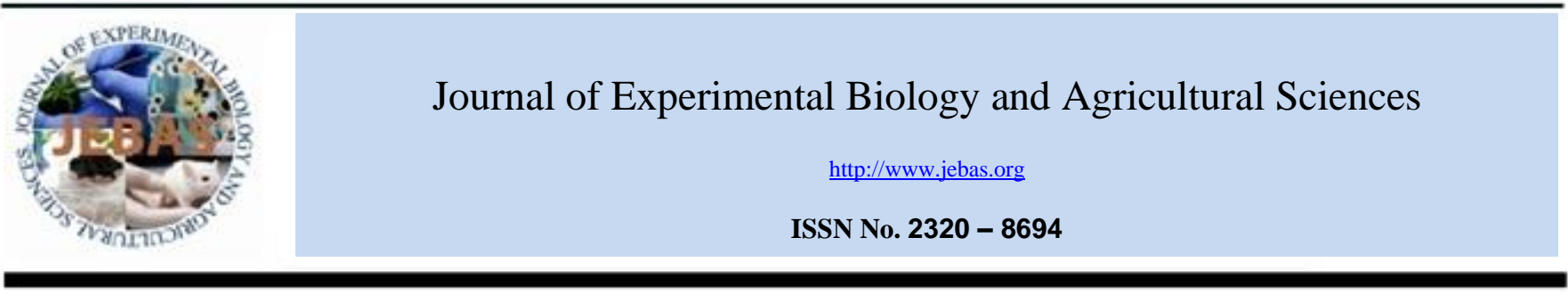

\title{
SERO-REACTIVITY PROTOTYPE OF SECRETED PROTEINS OF NATIVE 'S 5' VACCINE STRAIN TO HUMAN SERA POSITIVE FOR Mycobacterium paratuberculosis INFECTION
}

\author{
Saurabh Gupta ${ }^{1,2}$, Shoor Vir Singh ${ }^{2, *}$ and A.K. Bhatia ${ }^{1}$ \\ ${ }^{1}$ Department of Biotechnology, Microbiology \& Immunology, GLA University, Mathura, India \\ ${ }^{2}$ Microbiology Laboratory, Central Institute for Research on Goats, Makhdoom, PO-Farah, India \\ Received - December 31, 2016; Revision - March 10, 2017; Accepted - April 23, 2017 \\ Available Online - May 12, 2017 \\ DOI: http://dx.doi.org/10.18006/2017.5(2).188.194

KEYWORDS
M. paratuberculosis
Indian Bison type
Secretory proteins
SDS-PAGE
Immunoblotting

\begin{abstract}
The zoonotic prospective of Mycobacterium avium subspecies paratuberculosis (MAP) has been debated for almost a century because of similarities between Johne's disease (Paratuberculosis) in animals and Crohn's disease (CD) in humans. Diagnosis of disease is hampered due to the extensive sharing of antigenic epitopes among MAP and other mycobacterial species. Therefore, this study is a preliminary work evaluated the reactivity pattern of secretory proteins harvested from native vaccine strain (MAP ' $\mathrm{S} 5$ ') at different incubation time (8-12 weeks of growth). Analysis of secretory proteins was done by BioLogic LP chromatography system using Bio-Scale ${ }^{\mathrm{TM}}$ Macroprep(R) High Q column (strong anion exchanger) and chromatogram showed six narrow protein peaks at 12 weeks by LP Data View v1.03 software (BioRad). Profile of secretory proteins harvested at different weeks was obtained by sodium dodecyl sulfate polyacrylamide gel electrophoresis. Immunoblotting showed strong reactivity of three secretory proteins commonly recognized $(28,34-38$ and 42-45) with all three human sera positive for MAP infection. Additional 10 and 23-26 kDa proteins were recognized with two MAP infected human sera. Diagnostic potential of secretory proteins as a pool was evaluated using 'Indirect ELISA test'. Results showed a lower sensitivity and $100 \%$ specificity with respect to semi-purified protoplasmic antigen (sPPA). Developing 'ELISA based assay' using these sero-reactive proteins will serve as backbone of future paratuberculosis control programs in the country. Earlier studies established that till today there are no universal diagnostic kits available for chronic diseases like CD. Therefore, study recommends use of secretory proteins as 'marker antigens' to design assay for the specific diagnosis of 'active infection' in human beings.
\end{abstract}

* Corresponding author

E-mail: shoorvir_singh@rediffmail.com (Shoor Vir Singh)

Peer review under responsibility of Journal of Experimental Biology and Agricultural Sciences.

Production and Hosting by Horizon Publisher India [HPI] (http://www.horizonpublisherindia.in/).

All rights reserved.
All the article published by Journal of Experimental Biology and Agricultural Sciences is licensed under a Creative Commons Attribution-NonCommercial 4.0 International License Based on a work at www.jebas.org.

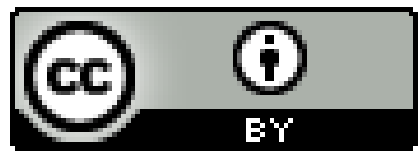




\section{Introduction}

Mycobacterium avium subspecies paratuberculosis (MAP), the cause of Johne's disease (JD), is endemic in domestic livestock population throughout the world (Singh et al., 2014a). Diagnosing of sub-clinically infected animals shedding MAP is difficult. MAP has widest host range and consistently reported from domestic and wild ruminants, free grazing animals (Singh et al., 2014a), primates and human beings suffering with autoimmune disorders such as Crohn's disease, Type 1 diabetes melitus, Hashimoto's thyroiditis, Autoimmune arthritis, Multiple sclerosis etc. (D'Amore et al., 2010; Cossu et al., 2013; Singh et al., 2014b; Sechi \& Dow, 2015; Singh et al., 2016).

Clinical symptoms of Crohn's disease closely mimic those found in animals suffering with Johne's disease. Since MAP is excreted through milk of infected domestic animals (Singh et al., 2014a), is therefore continuously entering human population through milk and milk products (Shankar et al., 2010). Economically MAP has high impact on dairy and beef industry and in US alone $<250$ million dollar losses has been reported (Ott et al., 1999). Control of paratuberculosis has been hampered due to lack of efficient and accurate diagnostics. Lowered specificity of tests can also be a problem due to the cross-reactivity and sharing of antigenic epitopes among MAP and with other species of Mycobacterium, Cornybacterium and Nocardia (Brennan \& Nikaido, 1995). Low sensitivity (13.6-33.3\%) of commercially available ELISA kits prepared using crude protoplasmic antigen has been reported by Singh et al. (2007). Recent studies have focused on the development of diagnostics using species-specific multiple protein antigens from native strains (Gupta et al., 2015; Chaubey et al., 2016). Micro-fluidics, Lab-on-Chip, PARA-LP-01 and PARASAFE are laboratory-free technologies developed for diagnosis of Mycobacterial infections (Wadhwa et al., 2012; Meyer \& Eckstein, 2012).

Earlier studies by Cho \& Collins (2006) found that secretory proteins were more reactive to sera from infected animals as compared to cell extract proteins. Few reports have been accessible on the reaction of serum antibodies from human positive for MAP infection with secretory proteins (Shin et al., 2010). Therefore to enhance sensitivity and specificity of diagnostic assays, it is proposed to use MAP specific sero-reactive proteins as 'marker antigens' for the detection of infection. Present work was conducted to study the antigenic profile of secretory proteins at 8 to 12 weeks (proteins excreted in mid to late incubation period) of MAP growth in liquid medium and also to establish the reactivity pattern of these proteins with polyclonal human sera positive for M. paratuberculosis infection in search of new candidate antigenic epitopes for the specific diagnosis of active infection by immunoblotting.

\section{Materials and Methods}

2.1 Bacterial strain and culture conditions
M. avium subspecies paratuberculosis ('S 5') 'Indian Bison type' vaccine strain (a new biotype of MAP not reported outside India) was isolated from a goat suffering with advance clinical disease at CIRG, Makhdoom in 1998. This strain was initially cultured on Middlebrook 7H9 medium (as per the manufacturer, Becton Dickinson, BD) supplemented with $10 \% \mathrm{v} / \mathrm{v}$ albumin-dextrosecatalase (ADC; Himedia), PANTA antibiotics and mycobactin $\mathrm{J}$ $\left(2 \mathrm{mg} / \mathrm{l}\right.$, Allied Monitor, Fayette) at $37^{\circ} \mathrm{C}$. MAP Growth in liquid medium (7H9) was monitored by taking absorbance (at $600 \mathrm{~nm}$ ) of the culture at third day, then every week for a period of 12 weeks. To check the growth of culture, turbidity was measured by Mcfarland standards. To reduce cell clumping, the MAP cultures were constantly shaken at $100 \mathrm{rpm}$ during incubation.

\subsection{Isolation and profiling of secretory proteins}

Secretory proteins were harvested at mid-late log phase of growth (8 and 12 weeks of incubation) at $37^{\circ} \mathrm{C}$ as described previously by Gupta et al. (2015). Briefly, bacterial cells were removed by centrifugation at $4000 \times g$ for $20 \mathrm{~min}, 4^{\circ} \mathrm{C}$ at different incubation time ( 8 and 12 weeks of growth). After filtration through $0.22-\mu \mathrm{m}$ pore size syringe filter (Millipore), the filtrate was concentrated with $10 \mathrm{kDa}$ Amicon Ultra $2 \mathrm{~mL}$ centrifugal filters (Sigma-Aldirch, India) and proteins were precipitated with saturated ammonium sulphate. Concentration of proteins was quantified by Bradford protein assay kit (Genei) and was stored at $-20^{\circ} \mathrm{C}$.

\subsection{Purification of secretory proteins}

Purification of secretory proteins was done by BioLogic LP chromatography system (Biorad) using Bio-Scale ${ }^{\mathrm{TM}}$ Macroprep (R) High Q column (strong anion exchanger). Chromatographic conditions were carried out as column type: Macroprep (R) High Q column (Strong anion exchanger); Binding Buffer (Buffer A): 50mM Tris-HCl, pH-8.6; Elution buffer (Buffer B): Buffer A with $1 \mathrm{M} \mathrm{NaCl}$ (Gradient 0 to100\%) at flow rate: $1 \mathrm{~mL} / \mathrm{Min}$. Chromatogram of secretory proteins (protein peaks) were analysed by LP Data View v1.03 software (BioRad).

\subsection{Human sera}

Informed consent and other necessary clearances were procured before blood samples were drawn to screen 44 patients suspected (having clinical symptoms) for the presence of MAP infection. Serum samples were categorized as positive and negative for MAP using 'Indigenous ELISA kit' developed and standardized by Singh et al. (2007). Polyclonal human sera from 3 patients diagnosed positive for MAP infection (confirmed by stool microscopy, IS900 blood PCR and 'Indigenous serum ELISA kit') were used for immunoblotting study.

2.5 Sodium Dodecyl Sulphate Polyacrylamide Gel Electrophoresis (SDS-PAGE)

Journal of Experimental Biology and Agricultural Sciences

http://www.jebas.org 
Secretory proteins profile was analyzed by $12 \%$ SDS-PAGE under reducing conditions and stained with Coomassie brilliant blue (R250) as per method given by Laemmli (1970).

\subsection{Immunoblotting}

MAP secretory proteins were transferred from polyacrylamide gels to PVDF-plus membrane (pore size $0.45 \mu \mathrm{m}$, Millipore) using Mini Trans-blot Cell (Bio-Rad) for $1.5 \mathrm{~h}$ at $60 \mathrm{~V}, 100 \mathrm{~mA}$ with some modifications as per Towbin et al. (1979). The membrane was blocked for $1 \mathrm{hr}$ at RT in 5\% skim (fat free) milk prepared in $1 \mathrm{X}$ Tris-buffered saline (TBS) with $0.05 \%$ Tween-20 (TBST). After blocking, secretory proteins were probed with primary antibody (polyclonal human serum) diluted $1: 100$ in $1 \times$ TBST for $2 \mathrm{hr}$ followed by washing 3 times ( 5 min each) with TBST. Antibody binding was detected by incubating the membrane with peroxidaseconjugated anti-human IgG (secondary antibody; Sigma-Aldirch, USA) using 1:2500 dilution for $1 \mathrm{hr}$ at RT, followed by washing 5 times with TBST. Visualization of sero-reactive protein bands was done by 3,3-Diaminobenzidine (DAB) (Sigma-Aldirch) in TBS (pH 7.6) with $30 \%$ hydrogen peroxide.

\section{7 'Indigenous serum ELISA Kit' (i-ELISA)}

The i-ELISA developed by Singh et al. (2007) by using semipurified protoplasmic antigen (sPPA) from native strain ' $\mathrm{S} 5$ ' of 'Indian Bison Type' MAP was used in this study. Optical densities (OD values) were transformed as sample-to-positive ( $\mathrm{S} / \mathrm{P})$ ratios as per the method of Collins (2002). The sensitivity and specificity of i-ELISA kit was 83.3 and $90.0 \%$, respectively (Singh et al., 2007).

\subsection{Secretory proteins based ELISA test (sp-ELISA)}

Secretory proteins (as a pool) harvested at 8 and 12 week of growth of MAP were used as per guide ling given by Singh et al (2007) at
$0.1 \mu \mathrm{g}$ per well of the microtiter plate. Briefly, test serum samples and conjugate anti-human horseradish peroxidase (Sigma Aldirch, USA) were used at 1:50 and 1:7000 dilutions, respectively and rest steps including interpretation of results were like i-ELISA kit.

\subsection{Analysis of sample to positive $(\mathrm{S} / \mathrm{P})$ ratio}

Ratio between mean OD of positive and negative control $(\geq 4$ times) was critical for calculating S/P ratio and were categorized as 0.00-0.09: negative; 0.10-0.24: suspected; 0.25-0.39: low positive; 0.40- 0.99: positive and 0.61-0.80: strong positive.

S/P ratio $=\quad[($ Mean Sample OD-Mean Negative OD $) /$ (Difference of Mean Positive OD and Negative OD)]

\subsection{Statistical Analysis}

McNemar's test and kappa agreement was applied to analyze the statistical significance between results of two tests using Instat GraphPad software, USA.

\section{Results}

\subsection{Profiling of secretory proteins by SDS-PAGE}

Chromatogram analysis of secretory proteins was done by strong anion exchanger chromatography system and reported six narrow protein peaks at 12 weeks by LP Data View v1.03 software (BioRad). Along with narrow protein peaks, chromatogram has shown a mixture of proteins as short peaks eluted at 0 to $100 \%$ gradient of $1 \mathrm{M} \mathrm{NaCl}$ (Figure. 1). SDS-PAGE of secretory proteins harvested at 8 and 12 weeks (mid-late log phase) showed that greater part of the secretory proteins had low molecular masses $(<70 \mathrm{kDa})$.

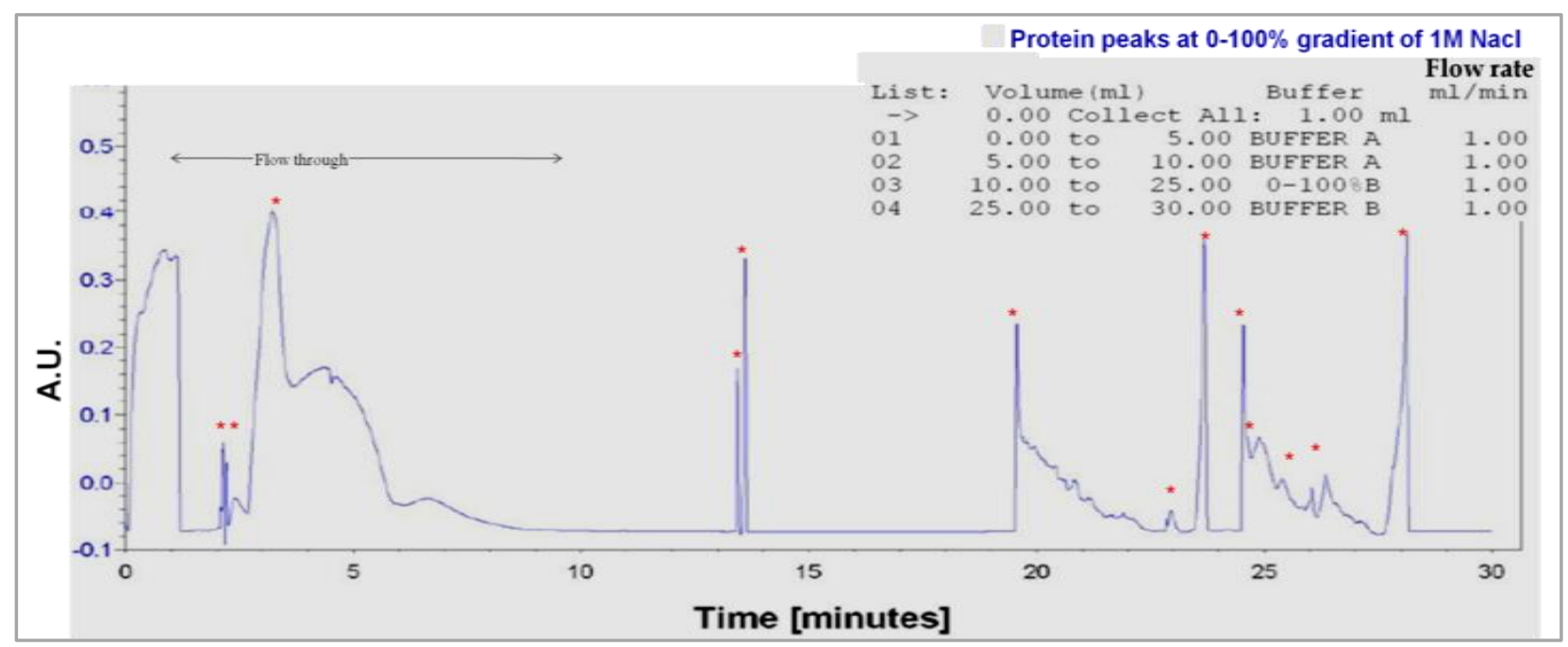

Figure 1 A typical chromatogram from an ion exchange purification using salt gradient elution. 


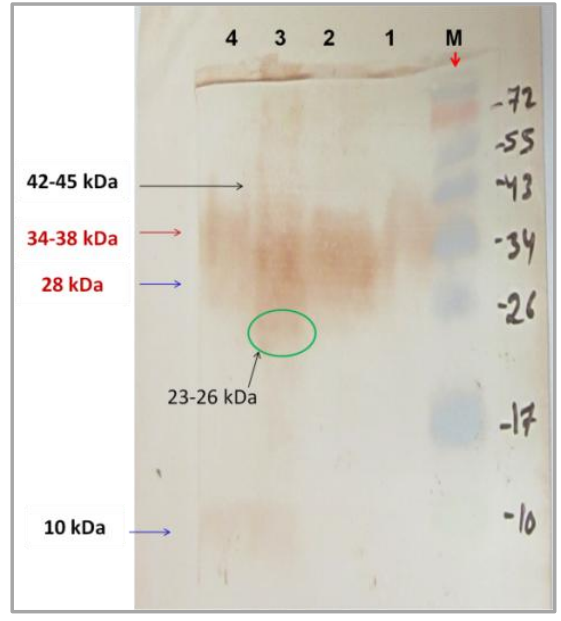

Figure 2 Immunoblots with secretory proteins of MAP in human serum 1 Lane M.

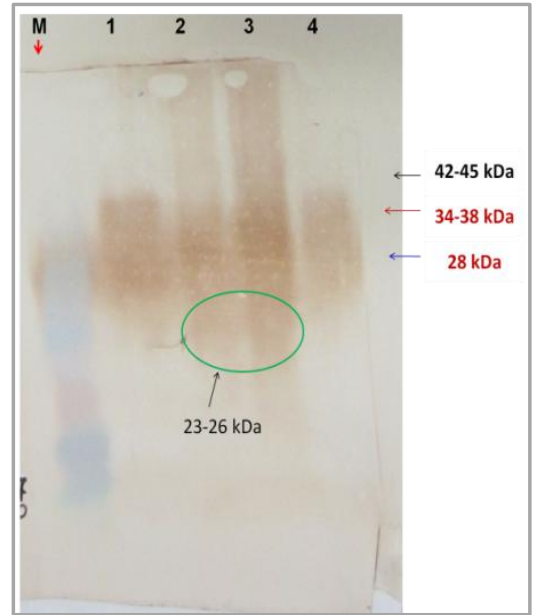

Figure 3 Immunoblots with secretory proteins of MAP in human serum 2 Lane M.

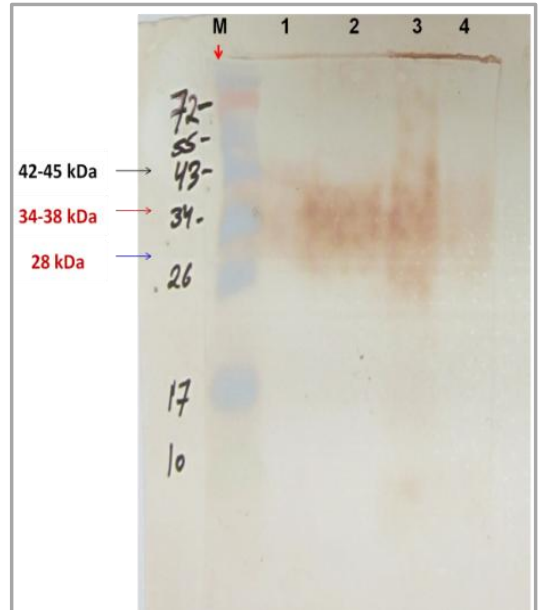

Figure 4 Immunoblots with secretory proteins of MAP in human serum 3 Lane M.

[Pre-stained protein marker, lane 1\&2: Secretory proteins at 8 weeks; lane 3\&4: Secretory proteins at 12 weeks.]

\subsection{Antibody responses to MAP Secreted Proteins}

Polyclonal human sera positive for MAP infection diagnosed and confirmed by fecal microscopy, IS900 blood PCR and 'Indigenous serum ELISA kit' were tested for antibody responses to secretory proteins. Immunoblotting showed variation in recognition pattern of secretory proteins harvested at 8-12 week (mid-late log phase of MAP) and three proteins as $28,34-38$ and $42-45 \mathrm{kDa}$ were commonly recognized with all 3 human sera (Figure. 2, 3 and 4). Furthermore, 10 and 23-26 kDa proteins were recognized using MAP infected human serum 1 and 2 and no reactivity was found with serum 3 (Figure. 2, 3 and 4). Immuno-blotting results indicated that secretory proteins were highly specific and were strongly reacted with the MAP positive human sera. Therefore, diagnostic potential of these reactive secretory proteins would be further evaluated using sera from infected patients and healthy controls were tested by ELISA assay in order to identify the 'biomarker antigens' for the detection of active MAP infection in human beings.

\subsection{Sero-diagnostic efficacy of sp-ELISA with respect to i-ELISA}

Secretory protein pools were used in sp-ELISA test so as to assess the sensitivity and specificity of the assay with respect to i-ELISA (Indigenous ELISA). Results of sp-ELISA test using above protein pools (8 and 12 weeks) as antigen showed improved specificity $(100.0 \%)$ as compared with semi-purified protoplasmic antigen (sPPA). Sensitivity of sp-ELISA at 8 and 12 weeks with respect to i-ELISA was 74.1 and $81.5 \%$, respectively (Tables 1 and 2). Kappa agreement calculated between sp-ELISA $\mathrm{A}_{4 \mathrm{~W}} v s$ i-ELISA and spELISA $_{6 \mathrm{~W}} v \mathrm{~s}$ i-ELISA were $0.688 \pm 0.103$ and $0.773 \pm 0.093$, respectively (Table 2). Strength of agreement was found good (kappa value: $0.61-0.80$ ) and statistically significant between the sp-ELISA and i-ELISA.

\section{Discussions}

Infections such as tuberculosis, bovine tuberculosis and paratuberculosis (paraTB) are major contagious diseases of both human and animals caused by mycobacterial species (Wadhwa et al., 2012). Both water and milk supplies have been suggested as vehicles of $M$. paratuberculosis transmission between animals and human beings (Pickup et al., 2006; Shankar et al., 2010). Currently available diagnostic methods for the detection of MAP infection are hampered by the lack of desired sensitivity and specificity including week's long duration to yield results. Several novel and improved diagnostic approaches have been discovered and they have made a remarkable effect on diagnosing the disease accurately (Shin et al., 2010; Singh et al., 2011; Garg et al., 2015). Several researchers have attempted to use of different antigens as semi purified protoplasmic antigen (sPPA), MBP fusion proteins and MAP recombinant proteins for diagnostic assays (Harinath et al., 2006; Cho et al., 2007; Singh et al., 2007; Gurung et al., 2013). However, the task has proved to be complex because many times an antigenic determinant may be shared among different species of genera Mycobacterium, Cornybacterium and Nocardial group of bacteria causing incorrect diagnosis of $M$. paratuberculosis. However, using recombinant proteins as antigen in ELISA assays, low specificity (loss or decrease in antigenicity) was reported which might be recognized due to conformational changes and/or glycosylation of protein during the cloning method (Cho et al., 2007; Shin et al., 2010). 
Table 1 Comparative evaluation of sp-ELISA vis a vis i-ELISA based on SPPA

\begin{tabular}{|c|c|c|c|c|}
\hline \multirow[t]{2}{*}{ S No } & \multirow[t]{2}{*}{ Status } & \multirow[t]{2}{*}{ i-ELISA (sPPA) } & \multicolumn{2}{|c|}{ sp-ELISA based on secretory proteins } \\
\hline & & & $8 \mathrm{~W}$ & $12 W$ \\
\hline 1 & Negative & 17 (38.6) & $18(41.0)$ & $18(41.0)$ \\
\hline 2 & Low positive & $00(0.0)$ & $06(13.6)$ & $04(9.1)$ \\
\hline 3 & Positive & $27(61.4)$ & $20(45.4)$ & $21(47.7)$ \\
\hline 4 & Strong Positive & $00(0.0)$ & $00(0.0)$ & $01(2.2)$ \\
\hline & Total $(n=44)$ & $27(61.4)$ & $20(45.4)$ & $22(50.0)$ \\
\hline
\end{tabular}

Table 2 Statistical analysis using McNemar's test and kappa values between sp-ELISA and i-ELISA

\begin{tabular}{|ll|llll|}
\hline Serum & Tests & $\begin{array}{l}\text { Two tailed } \mathrm{P} \\
\text { value }\end{array}$ & $\begin{array}{l}\text { Kappa } \pm \text { SE } \\
(95 \% \text { confidence interval })\end{array}$ & $\begin{array}{l}\text { Strength of } \\
\text { agreement }\end{array}$ & $\begin{array}{l}\text { Sensitivity \& } \\
\text { Specificity }\end{array}$ \\
\hline $\begin{array}{l}\text { Human } \\
(\mathrm{n}=44)\end{array}$ & $\begin{array}{l}\text { i-ELISA versus } \\
\text { sp-ELISA }\end{array}$ & $0.0233^{* *}$ & $\begin{array}{l}0.688 \pm 0.103 \\
(0.487 \text { to } 0.889)\end{array}$ & Good & $74.1 \& 100.0 \%$ \\
\cline { 2 - 6 } & $\begin{array}{l}\text { i-ELISA versus } \\
\text { sp-ELISA }\end{array}$ & 0.0736 & $0.773 \pm 0.093(0.590$ to 0.955$)$ & Good & $81.5 \& 100.0 \%$ \\
\hline
\end{tabular}

[*Humans in positive and strong positive categories were considered as positive in the ELISA tests $8 W \& 12 W$ : Secretory proteins harvested at 8 and 12 week of growth of MAP culture in liquid medium.

**Strength of agreement was good and difference is considered to be statistically significant i-ELISA was taken as standard for comparison]

Study conducted by Cho \& Collins (2006) suggested the use of secreted proteins as antigens in ELISA assays, resulting in enhanced assay sensitivity by $25.0 \%$ for low shedders. However, serological tests based on sero-reactive proteins have minimize the chances of sharing of antigenic epitopes among mycobacterial species and have utility in differentiation/diagnostics for BCG vaccinated humans or in human population residing in high tuberculosis burden countries. Although similar in sensitivity and specificity, the ELISA based on secretory proteins yielded a higher signal to noise ratio in MAP positive patients and were serologically superior as compared with Cell Extract antigens (Shin et al., 2010). Newer methods such as 'Lab-on-Chip' and 'microfluidics' are some modern diagnostics that can put prominence on development of laboratory free tests for the MAP infection (Wadhwa et al., 2012). Similarly, Wadhwa et al. (2014) developed a sensitive ELISA test (EVELISA) using ethanol extract of MAP for diagnosis of MAP infection.

Our earlier studies reported the high bio-load of MAP infection in the human population suffering with chronic inflammatory and auto-immune diseases, when screened with routine diagnostic tests (Singh et al., 2014b; Singh et al., 2016). So, in the absence of universal diagnostic kits in chronic diseases like $\mathrm{CD}$, present preliminary work was started to identify the sero-reactive secretory proteins of native and prevalent MAP ' $\mathrm{S} 5$ ' strain as new candidate antigenic determinant for the diagnosis of 'active infection' in human beings. Present work revealed that greater part of the secretory proteins had molecular low masses $(<70 \mathrm{kDa})$. Sung \& Collins (2003) have observed that appearance of MAP secretory protein depends on the strain type and culture conditions. Earlier study reported that protein expression of proteins may vary between strains isolated from two different species (Shin et al.,
2010). Earlier study also reported that more sero-reactive proteins may be secreted during short period of growth, which are not dominant in long term cultures (Valentin-Weigand \& Moriarty, 1992). Immunoblotting studies using human sera positive for MAP infection contained significant levels of antibodies against secretory proteins. Gupta et al. (2015) showed that above secretory proteins showed high degree of consistency in antibody recognition patterns when probed with MAP infected goats and sheep sera. In conclusion, study recommend use of secretory proteins as 'marker antigens' in ELISA assay and provided significant advantage in diagnosis of variable immune response due to 'active infection' in human beings.

\section{Acknowledgments}

Authors are thankful to the Directors (Central Institute for Research on Goats, Makhdoom and GLA University, Mathura) for providing laboratory and animal house facilities. We also thank Kundan K. Chaubey, Manju Singh and Zahra Hemati for their comments and suggestions in the preparation of the manuscript.

\section{Conflict of interest}

Authors would hereby like to declare that there is no conflict of interests that could possibly arise.

\section{References}

Brennan PJ, Nikaido H (1995) The envelope of mycobacteria. Annual Review Biochemistry 64: 29-63. DOI: 10.1146/annurev.bi.64.070195.000333. 
Chaubey KK, Gupta RD, Gupta S, Singh SV, Bhatia AK, Jayaraman S, Kumar N, Goel A, Rathore AS, Sahzad, Sohal JS, Stephen BJ, Singh M, Goyal M, Dhama K, Derakhshandeh A (2016) Trends and advances in the diagnosis and control of paratuberculosis in domestic livestock. Veterinary Quarterly 36: 203-227.

Cho D, Collins MT (2006) Comparison of the proteomes and antigenicity of secreted proteins and cellular proteins produced by Mycobacterium paratuberculosis. Clinical Vaccine and Immunology 13: 1155-1161. DOI:10.1128/CVI.00058-06.

Cho D, Shin SJ, Tallat AM, Collins MT (2007) Cloning, expression, purification and serodiagnostic evaluation of fourteen Mycobacterium paratuberculosis proteins. Protein Expression and Purification 53: 411-420. DOI: http://dx.doi.org/10.1016/j.pep.2006.12.022.

Collins MT (2002) Interpretation of a commercial bovine paratuberculosis enzyme-linked immunosorbent assay by using likelihood ratios. Clinical and vaccine Immunology 9: 13671371. doi: 10.1128/CDLI.9.6.1367-1371.2002.

Cossu D, Masala S, Sechi LA (2013) A Sardinian map for multiple sclerosis. Future Microbiology 8: 223-232. doi: 10.2217/fmb.12.135.

D'Amore M, Lisi S, Sisto M, Cucci L, Dow CT (2010) Molecular identification of Mycobacterium avium subspecies paratuberculosis in an Italian patient with Hashimoto's thyroiditis and Melkersson-Rosenthal syndrome.. Journal of Medical Microbiology 59: 137-139. DOI: 10.1099/jmm.0.013474-0.

Garg R, Patil PK, Singh SV, Sharma S, Gandham RK, Singh AV, Filia G, Singh PK, Jayaraman S, Gupta S, Chaubey KK, Tiwari R, Saminathan M, Dhama K, Sohal JS (2015) Comparative Evaluation of Different Test Combinations for Diagnosis of Mycobacterium avium subspecies paratuberculosis Infecting Dairy Herds in India. Biomed Research International Article ID 983978, http://dx.doi.org/10.1155/2015/983978.

Gupta S, Chaubey KK, Singh SV, Bhatia AK, Kumar N, Goel A, Sachan TK, Rawat KD, Sohal JS, Dhama K (2015) Immunoreactivity to culture filtrate proteins of Mycobacterium avium subspecies paratuberculosis in naturally infected goat and sheep sera. Advances in Animal and Veterinary Sciences 3: 347-353. DOI http://dx.doi.org/10.14737/journal.aavs/2015/3.6.347.353.

Gurung RB, Begg DJ, Purdie AC, Bannantine JP, Whittington RJ (2013) Antigenicity of Recombinant Maltose Binding Protein Mycobacterium avium subsp. paratuberculosis Fusion Proteins with and without Factor Xa Cleaving. Clinical and

Vaccine Immunology 20: 1817-1826. doi:
10.1128/CVI.00596-13.

Harinath BC, Kumar S, Roy SS, Hirudkar S, Upadhye V, Shende N (2006) A cocktail of affinity-purified antibodies reactive with diagnostically useful mycobacterial antigens ES31, ES-43, and EST-6 for detecting the presence of Mycobacterium tuberculosis. Diagnostic Microbiology and Infectious Disease 55: 65-68. DOI: 10.1016/j.diagmicrobio.2005.10.021.

Laemmli UK (1970) Cleavage of Structural Proteins during the Assembly of the Head of Bacteriophage T4. Nature 227: 680685. DOI: doi:10.1038/227680a0.

Meyer SK, Eckstein TM (2012) PARASAFE- A New Lipidbased Elisa for diagnosing cattle with Johnes Disease. In Proceedings: $11^{\text {th }} \quad$ International Colloquium on Paratuberculosis - ICP 2012, 5-10 February 2012, Sydney, Australia.

Ott SL, Wells SJ, Wagner BA (1999) Herd-level economic losses associated with Johne's disease on US dairy operations. Preventive Veterinary Medicine 40: 179-192.

Pickup RW, Rhodes G, Bull TJ, Arnott S, Sidi-Boumedine K, Hurley M, Hermon-Taylor J (2006) Mycobacterium avium subsp. paratuberculosis in lake catchments, in river water abstracted for domestic use, and in effluent from domestic sewage treatment works: diverse opportunities for environmental cycling and human exposure. Applied and Environmental Microbiology 72: 4067-4077. doi: 10.1128/AEM.02490-05.

Sechi LA, Dow CT (2015) Mycobacterium avium ss. paratuberculosis Zoonosis- The Hundred Year WarBeyond Crohn's Disease. Frontiers in Immunology 6: 96. DOI: https://doi.org/10.3389/fimmu.2015.00096.

Shankar H, Singh SV, Singh PK, Singh AV, Sohal JS, Greenstein RJ (2010) Presence, characterization, and genotype profiles of Mycobacterium avium subspecies paratuberculosis from unpasteurized individual and pooled milk, commercial pasteurized milk, and milk products in India by culture, PCR, and PCR-REA methods. International Journal of Infectious Diseases 14: e121-e126. doi: 10.1016/j.ijid.2009.03.031.

Shin AR, Kim HJ, Cho SN, Collins MT, Manning EJ, Naser SA, Shin SJ (2010) Identification of seroreactive proteins in the culture filtrate antigen of Mycobacterium avium ssp. paratuberculosis human isolates to sera from Crohn's disease patients. FEMS Immunology \& Medical Microbiology 58: 128-37. doi: 10.1111/j.1574-695X.2009.00617.x.

Singh AV, Singh SV, Verma DK, Yadav R, Singh PK, Sohal JS (2011) Evaluation of 'Indigenous Absorbed ELISA Kit' for

Journal of Experimental Biology and Agricultural Sciences http://www.jebas.org 
the Estimation of Seroprevalence of Mycobacterium avium subspecies paratuberculosis Antibodies in Human Beings in North India. ISRN Veterinary Science 636038. http://doi.org/10.5402/2011/636038.

Singh SV, Kuenstner JT, Davis WC, Agarwal P, Kumar N, Singh D, Gupta S, Chaubey KK, Kumar A, Misri J, Jayaraman S, Sohal JS, Dhama K (2016) Concurrent Resolution of Chronic Diarrhea Likely Due to Crohn's Disease and Infection with Mycobacterium avium paratuberculosis. Frontiers in Medicine 3:

49

DOI:

https://doi.org/10.3389/fmed.2016.00049.

Singh SV, Kumar N, Sohal JS, Singh AV, Singh PK, Agrawal ND, Gupta S, Chaubey KK, Deb R, Dhama K, Rawat KD (2014b) First Mass Screening of the Human Population to Estimate the Bio-load of Mycobacterium avium subspecies paratuberculosis in North India. Journal of Biological Sciences 14: 237-247. DOI: 10.3923/jbs.2014.237.247.

Singh SV, Singh AV, Singh PK, Sohal JS, Singh NP (2007) Evaluation of an indigenous ELISA for diagnosis of Johne's disease and its comparison with commercial kits. Indian Journal of Microbiology 47: 251-258. doi: 10.1007/s12088007-0046-2.

Singh SV, Singh PK, Singh AV, Sohal JS, Kumar N, Chaubey KK, Gupta S, Rawat KD, Kumar A, Bhatia AK, Srivastav AK, Dhama K (2014a) Bio-load' and bio-type profiles of Mycobacterium avium subspecies paratuberculosis infection in the domestic livestock population endemic for Johne's disease: a survey of 28 years (1985-2013) in India. Transboundary and Emerging Diseases 61: 43-55. doi: 10.1111/tbed.12216.

Sung N, Collins MT (2003) Variation in resistance of Mycobacterium paratuberculosis to acid environments as a function of culture medium. Applied and Environmental Microbiology 69: 6833-6840. doi: 10.1128/AEM.69.11.68336840.2003.

Towbin H, Staehelin T, Gordon J (1979) Electrophoretic transfer of proteins from polyacrylamide gels to nitrocellulose sheets: procedure and some applications. Proceedings of the National Academy of Sciences, USA 76: 4350-4354.

Valentin-Weigand P, Moriarty KM (1992) Protein antigens secreted by Mycobacterium paratuberculosis. Zentbl Veterinarmed 39: 762-766.

Wadhwa A, Hickling GJ, Eda S (2012) Opportunities for improved serodiagnosis of human tuberculosis, bovine tuberculosis, and paratuberculosis. Veterinary Medicine International 1-13. http://dx.doi.org/10.1155/2012/674238.

Wadhwa A, Johonson RE, Eda K, Waters WR, Palmer MV, Bannantine JP, Eda S (2014) Evaluation of ethanol vortex ELISA for detection of bovine tuberculosis in cattle and deer. BMC Veterinary Research 10: 147. DOI: 10.1186/1746-614810-147.

Journal of Experimental Biology and Agricultural Sciences

http://www.jebas.org 